\title{
Imágenes sin mundo: modernidad y extrañamiento
}

\author{
PUELLES ROMERO, Luis \\ Abada Editores, S.L. Madrid, 2017
}
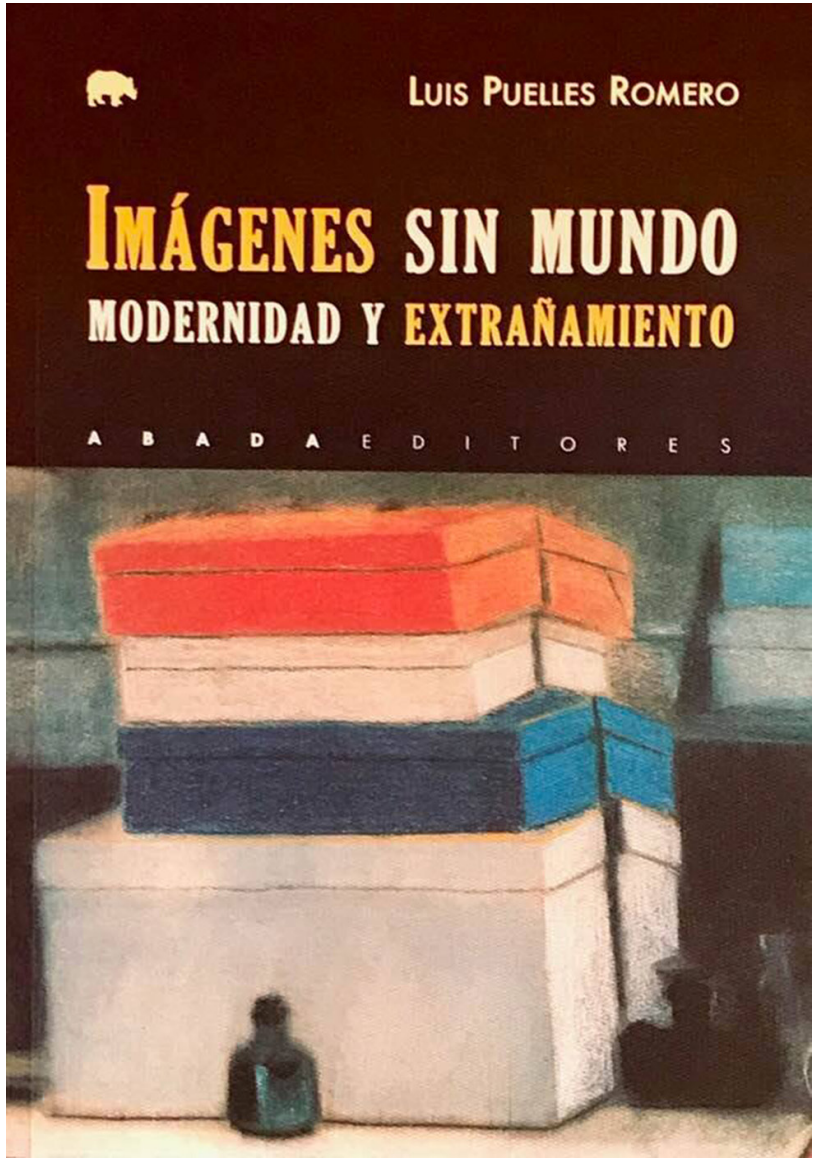

La editorial Abada trae a las librerías Imágenes sin mundo: modernidad y extrañamiento, el nuevo trabajo de Luis Puelles Romero, profesor titular de Estética y Teoría de las Artes de la Universidad de Málaga, autor de un considerable acervo de volúmenes de reflexión estética caracterizados por su voluntad ensayística y problematizadora, entre los que podemos mencionar Honoré Daumier: la risa republicana; Modos de sensibilidad o Mirar al que mira: teoría estética y sujeto espectador, por el que resultó ganador de la segunda edición del Premio Iberoamericano de Investigación Universitaria "Ciudad de Cádiz». Como temas recurrentes en su obra, podemos destacar el objeto surrealista, el estatuto del receptor de la obra de arte y los procesos de espectacularización del mundo contemporáneo.

En esta ocasión, Puelles vuelve a tratar aspectos que ya fueron objeto de su atención en el número de 2016 de la revista Contrastes, titulado Poéticas del extrañamiento, en el que participó como coordinador de un volumen que reunía trece artículos de otras tantas figuras relevantes de la reflexión estética de España, Francia y México, entre los que se encontraban Martine Renouprez, Maite Méndez Baiges y Didier Ottinger.

La representación puede definirse, observa Puelles, como el producto del entendimiento que permite al sujeto poner el mundo bajo su dominio, objetualizándolo e integrándolo en una trama de signos que cabría calificar, en última instancia, de antropomorfos. Operaciones mediante las que el sujeto puede recluirse en el interior de la atalaya de la conciencia. La modernidad se instaura, de la mano de momentos del pensamiento como las Meditaciones Metafísicas de Descartes, con la sospecha inquietante de que este entramado de significaciones que asignamos al mundo es una aportación subjetiva, que los sentidos que asignamos a las cosas han sido puestos por nosotros, que la conciencia no es más que una posición rígidamente mantenida.

Este es el punto de partida desde el cual abordar la comprensión de la imagen extrañante, la imagen-fantasma que nos fascina a la vez que nos extravía del mundo que creíamos comprender: la imagen, en definitiva, característica del estatuto de la modernidad. Hablamos de extrañamiento y no de extrañeza, nos aclara Puelles, pues lo que se nos propone va más allá de la mera sorpresa o admiración. Es una suerte de revelación que hace emerger lo insólito que se escondía en lo familiar y cotidiano, impidiendo integrar lo extraño en lo reconocible. Esta fractura entraña la confusión entre dos términos que deberían quedar nítidamente confrontados: el sujeto y el objeto, perturbando nuestra relación de dominio con el mundo de las supuestas evidencias. 
En efecto, gran parte de la singladura del arte moderno puede ser explicada como el proceso por el cual la imagen adquiere gradualmente un estatuto que rebasa lo meramente objetual. En vez de acercarnos o hacernos comprensible el mundo, estas imágenes viven una suerte de emancipación respecto a representaciones, significaciones y discursos legitimadores. Rechazan poder ser entendidas como símbolos o signos. Separan a la cosa de una perspectiva integradora del mundo.

Es lo artístico-visual resistiéndose a su verbalización, irguiéndose gradualmente y adentrándose en el espacio de seguridad que se interponía entre obra y receptor. El espectador queda expuesto a las turbulencias provenientes de imágenes que han escapado a la lógica del sentido. Es incapaz de entender aquello que le está haciendo sentir. Su experiencia es ahora la de sobrecogimiento al observar que el objeto se ha vuelto sujeto enigmático y perturbador, presencia ilógica: acontecimiento. Como ya apuntase Ortega, estamos hablando de un arte que se instaura a condición de abolir lo real. La modernidad consuma la subversión de los postulados platónicos, pues esta dinámica de fascinación por el fantasma relega a la metafísica de la verdad al lugar de postración que debía corresponder al entramado de las apariencias.

Puelles reconoce en las reflexiones medievales de Guillermo de Ockham o Duns Scoto el despertar de una mirada moderna que se posa en la individualidad de lo aparente, en una contingencia no remisible a nociones universales. Una mirada que percibe en las imágenes ocasión para un saber diferente al de los conceptos. La proliferación de los temas de las naturalezas muertas y del trompe-l'oeil es apuntada por Puelles como síntoma de este movimiento de liberación de la imagen que se afirma en su intrascendencia.

Con el renacimiento comienza el declive del concepto de cosmos ordenado, entendido como analogía visible del mundo de las verdades metafísicas, que es paulatinamente desplazado por una actitud moderna caracterizada por la praxis, por el empeño humano en adaptar el medio a sus intereses, deponiendo a la naturaleza de su filiación metafísica y haciéndola también a ella misma presa del artificio. Nos asomamos a un mundo al que no le irá quedando más sentido que el elaborado humanamente a través de un arte y unas ciencias antropocéntricas.

Desde el XVI los grutescos, carentes de cualquier significación discursiva o analógica, se extienden al igual que la idea de un universo infinito y carente de centro de Giordano Bruno. Es también la época del surgimiento de los temas de la vanitas y de la melancolía, donde el artista trabaja ofreciéndonos imágenes interrumpidas, inconexas, sustraídas de cualquier contexto de realidad. Pero quizá lo más característico de esta época sean las representaciones de la expulsión del paraíso de artistas como un Masaccio o un Pontormo: muestras de la conciencia renacentista de la condena que nos deja frente a la vergüenza de nuestra propia desnudez y que nos obliga a tener que crear para crearnos.

Desde la aparición de los grutescos hasta nuestros días, el arte moderno se irá poblando de monstruos, fantasmas e ilusiones cuyo poder de fascinación pugnará para retener continuamente la mirada del espectador. Ya en la segunda mitad del XVIII, Kant reconocerá a la imaginación la potestad de ser productora de lo nuevo que sobrepasa la capacidad del concepto, de engendrar aquello que no se deja atrapar por el entendimiento. Sólo como inaccesible al orden racional se nos aparece la imagen en su presencia irreductible. No obstante, conviene advertir que la imagen extrañante debe ofrecer un aspecto naturalista si pretende ser eficaz en su tarea de suplantación. De otra forma, el trompe-l'oeil no cumpliría su misión de proporcionarnos el placer negativo que conlleva la confusión del anverso y el reverso de lo real.

El anhelo romántico de alma y de presencia se revelará contra los fríos ideales de belleza y perfección. Durante las convulsiones estéticas del XIX se alcanza la culminación de la imagen artística como mímesis perfecta de la realidad, pero esto no consigue apaciguar el acoso de una plasticidad cada vez más ostentosa y menos referencial. Manet es el gran maestro de las estrategias de atracción de la mirada hacia imágenes que resisten la asimilación discursiva, de la pintura radicalmente visible gracias a su ininteligibilidad. Las últimas décadas del siglo, en el contexto del simbolismo y del decadentismo, sirven para dotar a las imágenes artísticas modernas de nuevos medios poiéticos para la provocación del extrañamiento, iniciando una senda que nos conducirá al surrealismo pasando por la pintura de metafísicos italianos como Carrá, Morandi o el propio Chirico, con su propósito de «penetrar en el enigma de las cosas consideradas generalmente insignificantes".

El siglo XX tiene un inicio fecundo en la exploración de estas poéticas del extrañamiento con figuras como Hofman- 
nsthal, Kafka, Pessoa, los surrealistas, etc. Las primeras aportaciones de Husserl al concepto de epojé, como puesta entre paréntesis de nuestros juicios respecto a la realidad, datan de 1916. Tres años más tarde ve la luz la primera versión de Lo siniestro de Sigmund Freud: la vivencia paradójica que nos hace aparecer lo familiar como irreconocible, como un objeto aterrador suspendido ante nosotros. Algo posterior es la reivindicación heideggeriana del carácter daimónico del arte, de su poder para presentar lo extraordinario de lo ordinario.

Conceptos nietzscheanos planean sobre gran parte de la reflexión estética del siglo. La última proposición formulada por Heidegger en su lectura sobre Nietzsche sostiene que el arte tiene más valor que la verdad, que «la voluntad de apariencia, de ilusión, de engaño, de devenir y cambio es más profunda, más metafísica que la voluntad de verdad, de realidad, de ser». Según las tesis nietzscheanas, la creencia en las verdades radica en el olvido de que no son más que ilusiones, por eso la actividad de la fantasía fundadora de la verdad debe mantenerse como un Sísifo incansable.

A estas aportaciones teóricas les acompaña una considerable apertura del abanico de posibilidades de expresión facilitada por la innovación conceptual de las vanguardias y los nuevos medios técnicos. El horizonte estético se puebla de muñecas, autómatas, títeres, figuras de cera, maniquíes, películas, fotomontajes, collages, etc. Dentro del ámbito surrealista, la obra de René Magritte aporta un enfoque que nos hace incomprender la imagen, abriendo una fractura entre lo aparente y lo textual, entre lo accesible visualmente y la posibilidad de coherencia discursiva. En este punto ubica Puelles el inicio de un cambio de rumbo aún más radical. La larga tradición de la imagen haciéndose soberana comienza a quedar reemplazada por un nuevo estado: el de las estrategias de suplantación de lo real por su falsificación fáctica.

En el estado de lo hiperreal descrito por Jean Baudrillard, el mundo es suplantado por signos estetizados de realidad, por simulacros. Se trata de una realización de la ficción que oculta los sentidos con los que poder acogernos a lo real. Si el destino de la conciencia artística moderna había sido la desautorización de aquello que nos venía tiranizando haciéndose pasar por real, Truman, el paradigmático personaje de la película de Peter Weir cuya vida transcurre en un espectáculo audiovisual sin posibilidad de pausa ni huida, se enfrenta ahora al reto de tratar de razonar contra la sobreabundancia de imágenes con pretensión de realidad que lo ocupan todo.

Los cambios en la concepción de lo que podríamos denominar el estatuto estético de la imagen son el vehículo por el que Puelles nos conduce por los momentos más relevantes de la modernidad a través de épocas y estilos, con el auxilio de más de setenta imágenes que abarcan un arco temporal de cinco siglos. De esta forma, consigue integrar en el mismo relato una larga serie de empresas artísticas que la historiografía al uso se ve obligaba a separar en estilos y tendencias diversos, mostrándonos un itinerario que constituye la historia de estos saberes secretos con los que fascinar y engañar, con los que la imagen se vuelve fantasma perturbador.

No obstante, estas reflexiones superan ampliamente el ámbito de lo artístico para proyectarse en lo estético que invade lo vivencial. Las inquietudes suscitadas por la verosimilitud de lo aportado por los sentidos tienen un largo predicamento en la historia de la filosofía. El enfoque propuesto por Puelles respecto de la imagen extrañante nos presenta un arte vivo en lucha contra las construcciones racionales de la filosofía y de la ciencia. Una pugna en la que, en última instancia, como señaló André Breton a propósito de Max Ernst, se combate en torno al principio de identidad.

Óscar Ortega Ruiz Universidad de Málaga 